\title{
Feasibility of polyculture of blue shrimp Litopenaeus stylirostris and goldlined rabbitfish Siganus lineatus in a mesocosm system
}

\author{
Trung Cong Luong ${ }^{a, c}$, Sebastien Hochard ${ }^{a}$, Florence Royer ${ }^{b}$, Hugues Lemonnier ${ }^{b, *}$, Yves Letourneur ${ }^{a}$ \\ a Université de la Nouvelle-Calédonie, Laboratoire LIVE, BP R4 - 98851 Nouméa Cedex, New Caledonia \\ b IFREMER, Lagons, Ecosystèmes et Aquaculture durable (LEAD/NC) BP 2059, 98846 Nouméa Cedex, New \\ Caledonia \\ ${ }^{c}$ Nha Trang University, 02 Nguyen Dinh Chieu Str., Nha Trang, Viet Nam \\ *: Corresponding author : Hugues Lemonnier, tel.: + 687285171 ; fax: + 687287857 ;
email address : $\underline{\text { hugues.lemonnier@ifermer.fr }}$
}

\begin{abstract}
:
The study was conducted to (1) estimate the effects of polyculture of blue shrimp Litopenaeus stylirostris with goldlined rabbitfish Siganus lineatus on production, environmental quality and water and sediment metabolism and (2) to determine if blue shrimp and goldlined rabbitfish polyculture is possible. The experiment was carried out for 12 weeks in a mesocosm system that consisted of 12 circular outdoor mesocosm fiberglass tanks $\left(1.7 \mathrm{~m}^{2}, 1275 \mathrm{~L}\right.$ water volume). Shrimp $(2.9 \mathrm{~g})$ were randomly stocked at density of 15 shrimp. $\mathrm{m}^{-2}$ without rabbitfish (control), with rabbitfish $(25.5 \mathrm{~g})$ at low density (1.2 fish. $\mathrm{m}^{-2}$ ) (LDRB) and high density $\left(2.4\right.$ fish. $\mathrm{m}^{-2}$ ) (HDRB). Results indicated that goldlined rabbitfish $S$. lineatus did not affect shrimp growth performance. At the end of the experiment, the combined shrimp and rabbitfish yields in the LDRB $\left(213 \mathrm{~g} \cdot \mathrm{m}^{-2}\right)$ treatment and the HDRB $\left(295 \mathrm{~g} \cdot \mathrm{m}^{-2}\right)$ treatment were significantly greater $(P<0.05)$ than the shrimp yield in the control $\left(143 \mathrm{~g} \cdot \mathrm{m}^{-2}\right)$. Most of the water and sediment parameters were similar among treatments. There was no significant difference $(P>0.05)$ in gross primary productivity and respiration between the HDRB treatment and the control. It was concluded that the polyculture of blue shrimp with goldlined rabbitfish is technically possible without degradation of the environment in the culture system.
\end{abstract}

\section{Highlights}

Siganus lineatus does not affect Litopenaeus stylirostris growth in a polyculture system. Polyculture $L$. stylirostris and $S$. lineatus significantly increases pond production. Adding S. lineatus to $L$. stylirostris culture does not impact environmental quality. Adding $S$. lineatus to $L$. stylirostris culture does not affect pond metabolism.

Keywords : Polyculture ; Penaeidae ; Siganidae ; integrated production ; environment ; pond ecology 


\section{Introduction}

Shrimp farming has been a major aquaculture activity worldwide and has rapidly expanded over the past three decades. Production of farmed shrimp increased from $\sim 88,000$ tonnes in 1981 to 3,788,000 tonnes in 2010 (FAO, 2010). However, shrimp aquaculture has faced many challenges during this time including disease, high production costs, fluctuating market prices and environmental management. The expansion of intensive shrimp culture has also increased environmental pollution due to enriched nutrient (total nitrogen: 34.6 - 133.1 $\mu \mathrm{M}$, and total phosphorus: $0.95-8.32 \mu \mathrm{M}$ ) and particulate matter (TSS: $15.2-109.3 \mathrm{mg} . \mathrm{L}^{-1}$ ) effluent discharged from shrimp farms (Thomas et al., 2010). Currently, the adverse impacts of these challenges and environmental pollution are so great that they are a threat to the sustainability of shrimp farming.

Shrimp polyculture has been shown to be an ecologically and economically sound method to increase the sustainability of shrimp culture (Akiyama and Angawati, 1999; Tian et al., 2001; Martínez-Córdova and Martínez-Porchas, 2006; Cruz et al., 2008), and shown to be an effective choice for solving and/or minimizing some of the current problems associated with shrimp culture (i.e. environmental pollution, disease and decreasing profitability) (MartínezPorchas et al., 2010). In recent years, research on shrimp polyculture has increased, showing in some cases, it can be successful and sustainable, both in freshwater and marine systems (García-Pérez et al., 2000; Martinez-Pochas et al., 2010; Yuan et al., 2010). Many species from various trophic levels, for instance seaweed (Kappaphycus alvarezii, Ulva clathrata) (Lombardi et al., 2006; Cruz-Suárez el at., 2010), mollusks (Sinonovacula constricta, Crassostrea gigas and Chione fluctifraga) (Tian et al., 2001; Martínez-Córdova and Martínez-Porchas, 2006) and fish (tilapias, mullets and milkfish) (Eldani and Primavera, 1981; Wang et al., 1998; García-Pérez et al., 2000; Yuan et al., 2010; Biswass et al., 2012) have been co-cultured with penaeid shrimps. Polyculture improved shrimp growth and quality (Akiyama and Angawati, 1999; Cruz-Suárez et al., 2010), raised production and economic benefits (García-Pérez et al., 2000; Tian et el., 2001; Yuan et al., 2010) and reduced environmental impacts (Tian et al., 2001; Yuan et al., 2010).

Some studies on the polyculture of penaeid shrimps with omnivorous fishes such as tilapia showed an improvement in water quality as fish fed on organic wastes (Akiyama and Angawati, 1999; Cruz et al., 2008), selectively fed on larger unicellular algae and larger zooplankton that increase the dominance of beneficial phytoplankton (Tian et al., 2001; Cruz 
et al., 2008), and increased nutrient retention in fish biomass (Wang et al., 1998; Yuan et al., 2010). Several fish species (tilapia, snapper, seabass and siganids) have the capacity to inhibit the growth of luminous bacteria Vibrio harveyi in shrimp rearing water and thus positively affect shrimp survival (Tendencia et al., 2006a, 2006b, 2006c; Cruz et al., 2008).

Monoculture shrimp farming in New Caledonia is affected by seasonal mortalities, both during the winter cold season ("Syndrome 93") (Mermoud et al., 1998), and during the warm season ("Summer Syndrome") (Goarant et al., 2006; Lemonnier et al., 2006). These two pathogens reduce the profitability of the industry and are therefore of great concern. In both cases, mortalities are related to septicemic vibriosis.

As reported by Tendencia et al. (2006a), siganids, herbivorous fish, are excellent candidates for shrimp polyculture and considered as species with high potential to decrease the impact of the disease, prevent the deterioration of the environment and to increase the production of the ponds. In this study, we conducted an experimental polyculture of blue shrimp Litopenaeus stylirostris with goldlined rabbitfish Siganus lineatus in a mesocosm system. The aims of our study were (1) to estimate the effects of blue shrimp and goldlined rabbitfish polyculture on production, environmental quality, and water and sediment metabolism and (2) to determine if blue shrimp and goldlined rabbitfish polyculture is possible.

\section{Materials and Methods}

\subsection{Experimental system}

The experiment was conducted for a period of 12 weeks, from shrimp stocking (August to November, 2012) at the Saint-Vincent Aquaculture Research Station, New Caledonia $\left(21^{\circ} 58^{\prime} \mathrm{N}, 165^{\circ} 57^{\prime} \mathrm{E}\right)$. The experiment was carried out in 12 circular outdoor mesocosm fibreglass tanks $\left(1.7 \mathrm{~m}^{2}\right)$. Sediment taken from earthen shrimp pond located at the research station was mixed and spread evenly in all the tanks up to $20 \mathrm{~cm}$ (per tank). This sediment was clay-like in texture and its organic content was $1.2 \%$. Each tank was equipped with a central standpipe for water outlet and a spherical air stone with a diameter of $4 \mathrm{~cm}$ suspended $10 \mathrm{~cm}$ above the sediment surface, from which aeration was continuously supplied to the tank. The tanks were filled with sand-filtered seawater one week before shrimp stocking. A daily water exchange of around $10 \%$ was applied by regulating individual valves in each tank 
and water height was maintained at $75 \mathrm{~cm}(1275 \mathrm{~L}$ in volume) above the sediment surface during the experiment.

\subsection{Experimental design}

Blue shrimp (L. stylirostris) juveniles $(2.9 \pm 1.1 \mathrm{~g})$ were randomly selected and stocked to the experimental tanks at density of 15 shrimp. $\mathrm{m}^{-2}$ (26 shrimp.tank $\left.{ }^{-1}\right)$. One month later, rabbitfish ( $S$. lineatus) were added to the shrimp tanks to form polyculture treatments. Rabbitfish $(25.5 \pm 2.9 \mathrm{~g}, 11.2 \pm 0.4 \mathrm{~cm}$ in total length), hatchery-reproduced, were stocked to shrimp tanks at either a low density (LDRB) of 1.2 fish.m ${ }^{-2}$ ( 2 fish.tank ${ }^{-1}$ ) or a high density (HDRB) of 2.4 fish.m ${ }^{-2}$ (4 fish.tank ${ }^{-1}$ ). Four additional shrimp monoculture tanks were used as a control treatment. All treatments were randomly distributed among tanks with four replicates per treatment. Shrimp in all tanks were fed similarly with commercial pellet feed (35-40\% protein, SICA Manufacturer, New Caledonia), twice daily at 8:00 am and 16:00 pm, with a feeding rate of $3-5 \%$ of shrimp biomass per day during the experiment. Feed quantity was adjusted using feeding trays $(30 \mathrm{~cm}$ diameter) placed in the control treatment tanks at seven day intervals. Feed was distributed over the entire bottom of the tank and on the feeding tray (20\% of total amount per time). Feed consumption on the tray was closely observed to determine and adjust the feed ration (Salame, 1993). The same amount of feed as for control tanks was applied to all other tanks. Rabbitfish were not given any supplementary feed after being added into the experimental tanks.

\subsection{Shrimp and fish sampling and analysis}

At stocking, 30 shrimps were randomly sampled and weighed individually to the nearest $0.1 \mathrm{~g}$. All fish at stocking and harvesting as well as all shrimp at harvesting in each tank were counted and weighed individually to the nearest $0.1 \mathrm{~g}$ and fish body total length (TL) were measured to the nearest $0.1 \mathrm{~cm}$ with a technical ruler.

Shrimp and rabbitfish growth performances were evaluated at harvesting in terms of survival, daily weight gain (DWG), specific growth rate (SGR), and yield.

Survival $(\%)=$ harvesting number/stocking number*100

DWG $\left(\right.$ g.day $\left.^{-1}\right)=$ weight gain $(\mathrm{g}) /$ time (days)

$\operatorname{SGR}\left(\% \cdot\right.$ day $\left.^{-1}\right)=(\operatorname{Ln~Wf}-\mathrm{Ln} \mathrm{Wi}) /$ time $($ days $) * 100$ 
Yield $\left(\mathrm{g} . \mathrm{m}^{-2}\right)=$ harvesting biomass $(\mathrm{g}) /$ area of culture tank $\left(\mathrm{m}^{2}\right)$

where Wi, Wf: shrimp/rabbitfish initial and final mean weight $(\mathrm{g})$

Coefficient of variation (CV) was calculated as the ratio of the standard deviation to the mean.

Shrimp food conversion ratio (FCR) was calculated as followed:

FCR $=$ total feed used (dry weight, g)/total shrimp weight gain (fresh weight, g)

Overall food conversion ratio (FCRsf) was calculated as followed:

FCRsf $=$ total feed used (dry weight, g)/total shrimp and fish weight gain (fresh weight, $\mathrm{g}$ )

\subsection{Water sampling and analysis}

Water temperature and dissolved oxygen (DO) concentrations were recorded twice daily (07:30 am and 15:00 pm) at mid depth of each tank using an OxyGuard meter (Handy Polaris). Salinity, turbidity and $\mathrm{pH}$ were measured three times a week (08:00 am) using a refractometer (Cond 3210, Welheim, Germany); turbidimeter (TN-100, Eutech Instruments, Singapore), and $\mathrm{pH}$ meter ( $\mathrm{pH}$ 197i, Welheim, Germany), respectively. On the day of rabbitfish stocking and once a week thereafter, water samples ( $2 \mathrm{~L})$ were collected in all tanks (08:00 am) at mid depth and filtered through pre-combusted $\left(450^{\circ} \mathrm{C}, 4\right.$ hours) GF/C Whatman fiberglass filters $(47 \mathrm{~mm})$. Filtered water were analysed for total ammonia nitrogen $\left(\mathrm{NH}_{4}{ }^{+}-\right.$ $\mathrm{NH}_{3}$ )-N, (TAN) (Koroleff, 1976), soluble reactive phosphorus (SRP) (Murphy and Riley, 1962), nitrite and nitrate $\left(\mathrm{NO}_{2}{ }^{-}-\mathrm{NO}_{3}{ }^{-}\right)-\mathrm{N}$ (Wood et al., 1967) and total dissolved nitrogen (TDN) (Raimbault et al., 1999). Dissolved organic nitrogen (DON) was expressed as the difference between total dissolved nitrogen and total dissolved inorganic nitrogen $\left[\left(\mathrm{NH}_{4}{ }^{+}-\right.\right.$ $\left.\left.\mathrm{NH}_{3}\right)-\mathrm{N}+\left(\mathrm{NO}_{2}{ }^{-}+\mathrm{NO}_{3}{ }^{-}\right)-\mathrm{N}\right]$. To estimate chlorophyll a, water sample of $25 \mathrm{~mL}$ was filtered through GF/F Whatman fiberglass filters $(25 \mathrm{~mm})$ and analysed by fluorometric methods (Holm-Hansen et al., 1965).

\subsection{Sediment sampling and analysis}

Sediments in all tanks were sampled on the day prior to the addition of rabbitfish and every two weeks thereafter from $1 \mathrm{~cm}$ deep cores by using $50 \mathrm{ml}$ cut-off syringes $(2.3 \mathrm{~cm}$ diameter). Sediment samples were collected at three different points within each tank and 
combined to provide one sample per tank for the analysis of organic matter content, $\mathrm{pH}$, redox potential and nutrient concentrations in pore water. The redox potential was estimated with a specific electrode (Consort P901, electrochemical analyzer, Beverly, MA, USA) and using the method described by Hussenot and Martin (1995). pH was directly measured by pushing the glass electrode ( $\mathrm{pH}$ 197i, Welheim, Germany) into freshly collected sediment in the sample vials. After that sediment samples were centrifuged at $2000 \mathrm{rpm}$ for 20 minutes. The supernatant parts (pore water) were used to analyse TAN and SRP following the methods as described above for water. The sediment samples were dried at $60^{\circ} \mathrm{C}$ for one week and then analysed for loss on ignition in a muffle furnace at $350^{\circ} \mathrm{C}$ for 8 hours (Nelson and Sommers, 1996). Sediment chlorophyll $a$ concentration was analysed from three different samples ( $1 \mathrm{~cm}$ core layer) per tank following the method from Holm-Hansen et al. (1965).

\subsection{Water and sediment metabolism}

Primary productivity (PP) and respiration (R) were measured in the HDRB treatment and the control to compare between polyculture and monoculture treatments. On the day prior to rabbitfish stocking and every two weeks thereafter, $\mathrm{PP}$ and $\mathrm{R}$ were determined by using the light and dark bottle method (Strickland and Parsons, 1972) under natural light. Two pairs of light and dark bottles were incubated in the water column at $20 \mathrm{~cm}$ under water surface and $20 \mathrm{~cm}$ above the sediment surface, respectively. Two chambers (light and dark) were set up on the bottom sediment. DO concentrations were recorded in the bottles and in the chambers every hour, between 10:30 am and - 13:30 pm, using an Oxygenmeter (Fibox 3 LCD - trace, Present, Germany).

Net primary productivity (NPP) and R were assessed as the rates of oxygen variations in the incubated bottles and in the chambers. NPP, R and gross primary productivity (GPP) were calculated for the water column and sediment using followed formulas.

$$
\begin{aligned}
& \mathrm{NPP}_{\mathrm{w}}=(\mathrm{Slsb}+\mathrm{Slbb}) / 2 * \mathrm{H}^{*} 1000 \\
& \mathrm{R}_{\mathrm{w}}=(\mathrm{Sdsb}+\mathrm{Sdbb}) / 2 * \mathrm{H}^{*} 1000 \\
& \mathrm{NPP}_{\mathrm{s}}=(\mathrm{Slc}-\mathrm{Slbb}) *(\mathrm{~V} / \mathrm{S}) * 1000 \\
& \mathrm{R}_{\mathrm{s}}=(\mathrm{Sdc}-\mathrm{Sdbb}) *(\mathrm{~V} / \mathrm{S}) * 1000 \\
& \mathrm{GPP}=\mathrm{NPP}+\mathrm{R}
\end{aligned}
$$

where $\mathrm{NPP}_{\mathrm{w}}$ : net primary productivity of the water column $\left(\mu \mathrm{mol} . \mathrm{m}^{-2} \cdot \mathrm{h}^{-1}\right)$; Slsb: oxygen slope in light surface bottle $\left(\mu \mathrm{mol} . \mathrm{L}^{-1} \cdot \mathrm{h}^{-1}\right)$, Slbb: oxygen slope in light bottom bottle $\left(\mu \mathrm{mol} . \mathrm{L}^{-1} \cdot \mathrm{h}^{-1}\right)$; $\mathrm{R}_{\mathrm{w}}$ : respiration of water column $\left(\mu \mathrm{mol} \cdot \mathrm{m}^{-2} \cdot \mathrm{h}^{-1}\right)$, Sdsb: oxygen slope in dark surface bottle 
$\left(\mu \mathrm{mol} \cdot \mathrm{L}^{-1} \cdot \mathrm{h}^{-1}\right)$, Sdbb: oxygen slope in dark bottom bottle $\left(\mu \mathrm{mol} \cdot \mathrm{L}^{-1} \cdot \mathrm{h}^{-1}\right) ; \mathrm{H}$ : the height of the water column $(\mathrm{m})$. NPP $\mathrm{s}$ : net primary productivity of sediment $\left(\mu \mathrm{mol} \cdot \mathrm{m}^{-2} \cdot \mathrm{h}^{-1}\right)$, Slc: oxygen slope in the light chamber $\left(\mu \mathrm{mol} \cdot \mathrm{L}^{-1} \cdot \mathrm{h}^{-1}\right) ; \mathrm{R}_{\mathrm{s}}$ : respiration of sediment $\left(\mu \mathrm{mol} \cdot \mathrm{m}^{-2} \cdot \mathrm{h}^{-1}\right)$; Sdc: oxygen slope in the dark chamber $\left(\mu \mathrm{mol} . \mathrm{L}^{-1} \cdot \mathrm{h}^{-1}\right)$; V: volume of the benthic chamber $\left(\mathrm{m}^{3}\right)$, and $\mathrm{S}$ : surface area of the benthic chamber $\left(\mathrm{m}^{2}\right)$; GPP: gross primary productivity $\left(\mu \mathrm{mol} \cdot \mathrm{m}^{-2} \cdot \mathrm{h}^{-1}\right)$

Oxygen self-produced budget from oxygen metabolism in whole tank was estimated as differences between total GPP and total R during day long.

$$
\mathrm{OB}=\left(\sum \mathrm{GPP} * 12\right)-\left(\sum \mathrm{R} * 24\right)
$$

where OB: oxygen self-produced budget $\left(\mathrm{mgO}_{2} \cdot \mathrm{m}^{-2} \cdot \mathrm{d}^{-1}\right)$; GPP $\left(\mathrm{mgO}_{2} \cdot \mathrm{m}^{-2} \cdot \mathrm{h}^{-1}\right)$ : gross primary productivity in whole tank; $\mathrm{R}\left(\mathrm{mgO}_{2} \cdot \mathrm{m}^{-2} \cdot \mathrm{h}^{-1}\right)$ : respiration in whole tank; 12: the duration (hour) of photoperiod during the experiment, and 24: the duration (hour) of respiration.

Shrimp oxygen demand was calculated based on shrimp predicted biomass $\left(\mathrm{g} \cdot \mathrm{m}^{-2}\right)$ in the culture tank and respiration rate $\left(\mathrm{mgO}_{2} \cdot \mathrm{g}^{-1} \cdot \mathrm{d}^{-1}\right)$ for L. Stylirostris (Wabete et al., 2008) during the experiment.

Gross natural production in the term of organic product produced by photosynthesis, expressed by $\mathrm{gC} \cdot \mathrm{m}^{-2} \cdot \mathrm{d}^{-1}$, was converted from total GPP, as follow:

$$
\mathrm{GNP}=(\Sigma \mathrm{GPP} * 12) / 32 / 1000
$$

where GNP: gross natural production $\left(\mathrm{gC} \cdot \mathrm{m}^{-2} \cdot \mathrm{d}^{-1}\right), \sum \mathrm{GPP}\left(\mathrm{mgO}_{2} \cdot \mathrm{m}^{-2} \cdot \mathrm{d}^{-1}\right)$ : total gross primary productivity in whole tank in day 12: carbon atomic density weight, and 32: oxygen molecular weight.

The quantity of carbon supplied daily to the tank through feeding was considered to account for $42.5 \%$ of dry weight of feed pellet (unpublished data).

\subsection{Statistical analysis}

All data were checked for normality (Kolmogorov-Smirnov test) and homogeneity of variances (HOV, Brown Forsythe test), and statistically analysed using one-way ANOVA with IBM SPSS software 16.0; with possible differences among data being tested by Duncan's multiple range tests. Percent data were arcsine-transformed before statistical analyses. Statistical comparisons of experimental data among treatments were performed for overall mean values and for each time of analyses. Non-parametric tests (Kruskal-Wallis test, H test) and Tamhane's T2 (Post-hoc, one-way ANOVA) were used when data were not normally distributed or the variances were heterogeneous. 
The water and sediment PP and R between the HDRB treatment and the control were statistically compared by using a paired Student's t-test in MS-Excel.

\section{Results}

\subsection{Shrimp and fish growth performances}

Shrimp final mean weight, survival, DWG, SGR, and yield were not significantly different $(\mathrm{P}>0.05)$ among treatments. The variability in shrimp survival and yield among replicates of each treatment reduced from the control to the HDRB treatment (Table 1).

Rabbitfish survival was $100 \%$ in all polyculture treatments. Rabbitfish final mean weight, DWG, and SGR were similar between the LDRB and the HDRB treatments (Table 1). The rabbitfish yield was significantly higher $(\mathrm{P}<0.05)$ in the HDRB than in the LDRB treatment. Similarly, the total combined shrimp and rabbitfish yield was significantly higher $(\mathrm{P}<0.05)$ in the HDRB treatment than in the LDRB treatment, and the total production in polyculture treatments was significantly greater $(\mathrm{P}<0.05)$ than shrimp production alone in the control (Table 1).

Shrimp food conversion ratio was not significant different $(\mathrm{P}>0.05)$ among treatments. However, the overall FCR was significantly lower $(\mathrm{P}<0.05)$ in the HDRB treatment than that in the control (Table 1).

\subsection{Water quality parameters}

Mean values and temporal variation trends (not shown) in temperature, DO, salinity, and $\mathrm{pH}$ were similar for all treatments. Salinity and $\mathrm{pH}$ ranged from 36 to 36.1 and from 8.1 to 8.2, respectively. In general, temperature and DO fluctuated within suitable ranges for shrimp and rabbitfish growth (Table 2). Mean turbidity and Chl $a$ were not significantly different ( $\mathrm{P}>0.05)$ among treatments (Table 2). However, Chl $a$ temporal variations showed slightly different trends among treatments (Fig. 1). Large standard deviations of Chl $a$ values in the control at the end of the experiment indicated a high variability among replicates for this treatment at that time. The phaeopigment ratio was similar in all treatments (Table 2). 
Except for SRP, mean nutrient concentrations (TDN, TAN, etc) were similar for all treatments (Table 2). Different trends in TAN temporal variations were observed among treatments (Fig. 1). Mean SRP concentration was significantly higher $(\mathrm{P}<0.05)$ in the LDRB treatment than in the HDRB treatment and the control. SRP temporal variation showed a strong increase in the LDRB in the last four weeks whilst the other treatments showed a similar trend with a slow increase at the end of the experiment (Fig. 1).

\subsection{Sediment parameters}

No significant differences were observed in all sediment parameters among polyculture treatments and the control (Table 3). Trends in redox potential were similar across all treatments. However, there was high variability among replicates of each treatment. Polyculture treatments and control treatment had the same trend in sediment Chl $a$ variation throughout the experiment (Fig. 2), with fluctuation over the first four weeks and a gradual increase during the last four weeks.

\subsection{Water and sediment metabolism}

There was no significant difference $(\mathrm{P}>0.05)$ in GPP and $\mathrm{R}$ between the HDRB treatment and the control. The trend of GPP temporal variation was different between two treatments (Fig. 3). GPP was significantly different $(\mathrm{P}<0.05)$ between the water column and sediment within each treatment. GPP dominated in water column and had opposite trend of temporal variation with sediment in both treatments (Fig. 3).

The trend of $\mathrm{R}$ temporal variation was different between the HDRB and the control (Fig. 4). Within each treatment, $R$ was significantly higher $(\mathrm{P}<0.05)$ in the water column than in sediment (Fig. 4). Sediment R temporal variation had same trend in both treatments (Fig. 4).

\section{Discussion}

Shrimp growth performance, including final mean weight, DWG and SGR, were not significantly different among polyculture treatments and the control, indicating that the presence of rabbitfish had no negative effect on shrimp growth. One problem in polyculture shrimp with free-swimming fish is that competition for food could potentially negatively affect shrimp growth (Wang et al., 1998; García-Pérez et al., 2000; Yuan et al., 2012) 
because fish are faster swimmers than shrimp and quickly monopolize the feed. Rabbitfish are herbivorous and gregarious fishes (Lam, 1974), and are thought to exhibit low competitive behaviour even when reared at high densities (Saoud et al., 2007). In captivity, rabbtifish become opportunistic omnivores and can feed on a great variety of foods such as aquatic plants, cooked rice, chopped fish or mollusks, fish meal, and pellets (Ben-Tuvia et al., 1973; Lam, 1974). When polycultured with shrimp, rabbitfish consume uneaten feed, and thus prevent further deterioration of the environment (Tendencia et al., 2006a). In our study, it was expected that goldlined rabbitfish would eat uneaten pellet feed offered to shrimp for their growth and that interspecies competition for food would be so low that it would have no negative effect on their growth and survival.

Shrimp growth in this study was similar with the result recorded for blue shrimp reared in earthen ponds (0.14 - 0.16 g. $\mathrm{d}^{-1}$; Lemonnier and Faninoz, 2006), but lower than those of blue shrimp monocultured in tanks (0.17 - 0.33 g.d $\mathrm{d}^{-1}$; Kumaraguru vasagam et al., 2009). Quite low temperatures (Table 2) could be one of the possible reasons for the "low" growth of shrimp in our results. The temperature range for growing L. stylirostris is $20-30{ }^{\circ} \mathrm{C}$ (Bondad-Reantaso et al, 2005; Spanopoulous-Hernández et al., 2005), and the optimum temperature is reported to be about $28{ }^{\circ} \mathrm{C}$ (Díaz et al., 2004; Bondad-Reantaso et al, 2005). Díaz et al. (2004) emphasized that thermal stress of L. stylirostris would increase as temperatures decreased or increased with respect to the optimum temperature of $28{ }^{\circ} \mathrm{C}$. Wabete et al. (2008) reported that the lower limit of the thermo-preferendum for $L$. stylirostris is $20-22{ }^{\circ} \mathrm{C}$, and also showed that at 20 to $22{ }^{\circ} \mathrm{C}$ shrimp were thermally stressed and often died after 2 days. In our experiment, water temperature fluctuated over the lower half of the temperature range for L. stylirostris growth. Morning temperatures were even below the lower limit of this range (Table 2). This low water temperature might have negatively affected shrimp growth, survival and food conversion ratio (Wyban et al., 1995).

Adding rabbitfish in our experiment decreased the variability of shrimp survival observed between replicates. This suggested that rabbitfish activity caused a possible increase in the stability of environmental conditions in tanks subsequently reducing shrimp mortality in some tanks. However, this hypothesis is not yet well supported and should be tested in further experiments. Shrimp mortality was observed, particularly at the end of the experiment when the eutrophication level of the ecosystem was highest as already observed in production ponds (Lemonnier et al., 2006). The water quality parameters were similar among treatments and varied within ranges (Table 2 and Fig. 1) that were unlikely to cause shrimp mortality. 
TAN concentrations were well below safe levels of ammonia recommended for rearing penaeid shrimp, $4.26 \mathrm{mg} . \mathrm{L}^{-1}(304.3 \mu \mathrm{M})$ TAN and $0.08 \mathrm{mg} . \mathrm{L}^{-1}(5.7 \mu \mathrm{M}) \mathrm{NH}_{3}-\mathrm{N}$ (Chen et al., 1990); or for growth-out pond, $\mathrm{NH}_{3}-\mathrm{N}<0.15 \mathrm{mg} . \mathrm{L}^{-1}(10.7 \mu \mathrm{M})$ (Lazur, 2007). The $\left(\mathrm{NO}_{2}+\mathrm{NO}_{3}\right)-\mathrm{N}$ concentrations were also well under safe levels of nitrite for rearing penaeid shrimp, $10.6 \mathrm{mg} . \mathrm{L}^{-1}$ (757.1 $\left.\mu \mathrm{M}\right)$ (Chen et al., 1990); or for grow-out ponds, $4.5 \mathrm{mg} . \mathrm{L}^{-1}$ (321.4 $\mu \mathrm{M}$ ) (Lazur, 2007). $\mathrm{pH}$ in sediment and the water column varied within narrow and suitable ranges $(6.5-8.0)$ for animal health and growth in all treatments (Lemonnier et al., 2004). The effect of hypoxic conditions on TAN accumulation may have a negative impact on shrimp growth (Joyni et al., 2011) and lead to mortality. However, mean TAN in pore water in this study were lower than stressful values recorded in a shrimp pond in New Caledonia (288.6 - 607.9 $\mu \mathrm{M}$, Mugnier et al., 2006) and were below safe levels of TAN defined for rearing penaeid shrimp, $304.3 \mu \mathrm{M}$ TAN (Chen et al., 1990).

Rabbitfish gained survival of $100 \%$ and had high growth rate $\left(0.5-0.6\right.$ g.d $\left.{ }^{-1}\right)$, and growth performance was similar at all rabbitfish stocking densities. This growth of rabbitfish indicated that food supplied in tanks was sufficient for rabbitfish and the tank environment might be able to support even more rabbitfish biomass. The polyculture of blue shrimp $L$. stylirostris with rabbitfish S. lineatus resulted in a significant increase in total production compared with shrimp monoculture. Furthermore, polyculture significantly decreased overall FCR by $31.6 \%$ and $47.4 \%$ in the LDRB and the HDRB treatments, respectively, compared with the control. Higher total production and lower overall FCR in rabbitfish polyculture contributed to increasing benefit.

Mean Chl $a$ concentrations were not significantly different among polyculture treatments and the control. This might be due to equal nutrient inputs provided into the tanks from pellet food supplied and water intake daily. Furthermore, rabbitfish, in juvenile and adult stages, were unlikely to be feeding on phytoplankton (Lam, 1974).

Most nutrient concentrations were low and varied within small ranges during our experiment. This indicated that water quality remained stable over the course of the experiment in all tanks. DON accounted for $87.3-95.8 \%$ of TDN in all treatments. In growing ponds, DON derives from formulated feed leaching, gill excretion and faeces leaching, and is one of the major sources of nitrogen in pond water (Burford and William, 2001). The low TAN concentration was likely due to absorption by phytoplankton. This 
would also explain the decrease of TAN in the control tanks coinciding with a rapid increase of Chl $a$ at the end of the experiment.

The changes of GPP in the water column and in sediment followed opposite trends in the HDRB polyculture and control treatments. As phytoplankton biomass increased, light availability at the bottom was reduced, resulting in limited photosynthesis of microphytobenthos. This process might also be enhanced by resuspended particulate matter caused by rabbitfish and/ or shrimp activities. Furthermore, in well-mixed or turbulent environments, resuspension of benthic microalgae attached to sediment particles also contributed significantly to GPP in water columns (MacIntyre et al., 1996). As increasing organic matter loads accumulated in the tanks, bacterial decomposition processes increased continuously, leading to increasing oxygen demand throughout the experiment in the water columns as well as in sediments in both treatments (Fig. 4). Suplee and Cotner (1996) found an increase in the sediment oxygen demand throughout the shrimp growing season, and Ellis (1992) reported that sediment oxygen demand consisted of more than $50 \%$ of the total shrimp pond oxygen demand at the end of the growing season. Our results agreed with these findings.

In general, total GPP of water and sediment tended to reduce from middle to the end of the experiment (Fig. 3), while total $\mathrm{R}$ in entire tank increased throughout the experiment (Fig. 4 ) in both treatments. These processes led to the differential oxygen amount between daily GPP and R in entire tank tended to decrease close to the end of the experiment (Fig. 5). In the HDRB treatment, oxygen budget generated from daily GPP and R was lower than estimated shrimp oxygen demand (not including rabbitfish oxygen demand) at the end day. Whilst in the control, the oxygen budget could fulfil shrimp oxygen demand over the course of the experiment (Fig. 5). However, the tanks were continuously supplied aeration and further sources from air diffusion and water inflow (10\% volume per day) provided oxygen to the tanks that maintained DO concentration in suitable ranges for cultured animal demand during the experiment (Table 2). To develop polyculture in semi-intensive earthen ponds, our results suggest that extra oxygen will be needed such as aeration to satisfy the animal's growth requirements.

GNP, in term of organic matter, produced by algae in the tanks was higher than organic carbon sources from food ration provided in both treatments (Fig. 6). Most of produced GNP might transfer to the bottom through sedimentation and to the surrounding environment 
through water exchange. This organic matter source can be considered as lost for the culture. This primary organic source could be consumed and transferred through the food web and ultimately be converted to animal biomass and thus contributed to increase production. In crustacean-fish polyculture, the use of artificial substrates, has showed good results because the contact surface is increased, promoting biotic communities such as phytoplankton, zooplankton and periphyton, which contribute to the nutrition of the shrimp and the cocultured species (Martínez-Porchas et al., 2010). In prawn-tilapia polyculture ponds, Uddin et al. (2007) placed bamboo sticks as substrates for periphyton growth, which resulted in a more favourable environment and provided an extra source of food for both species. Blue shrimp can utilize a wide variety of food, such as detritus, macroalgae, exuviae, prey and formulated feed in semi-intensive ponds (Martínez-Córdova and Pena-Messina, 2005). Rabbitfish are herbivores and primarily feed on benthic algae and filamentous algae (Lam, 1974). Our results, suggest that an important area for further research is the use of artificial substrates to promote periphyton development, which could provide an extra food source for both blue shrimp and goldlined rabbitfish and reduce pellet feed use and nutrient loss to the environment.

\section{Acknowledgements}

We are very grateful to the laboratory technical staff at IFREMER, IRD (LAMA) and New Caledonia University for their help in sample analysis. We also thank Dr Thierry Laugier and Dr Abi Powell for critical reading of the manuscript. This study was supported by grant from the South Province of New Caledonia and carried out at the IFREMER SaintVincent Aquaculture Research Station and the New Caledonia University.

\section{References}

Akiyama, D.M., Anggawati, A.M., 1999. Polyculture of shrimp and tilapia in East Java. American soybean Association (ASA), Technical Bulletin AQ 47.

Ben-Tuvia, A., Kissil, G.Wm., Popper, U. 1973. Experiments in rearing rabbitfish (Siganus rivulatus) in sea water. Aquaculture 1, 359-364. 
Biswas, G., Ananada Raja, R., De, D., Ghoshal, T.K., Anand, S., Kumar, S., Panigrahi, A., Thirunavukkarasu A.R., Poniah, A.G., 2012a. Evaluation of productions and economic returns from two brackishwater polyculture system in tide-fed ponds. Journal of Applied Ichthyology 28, 116-222.

Bondad-Reantaso, M.G., Lovell, E.R., Arthur, J.R., Hurwood, D., Mather, P.B., 2005. Pathogen and ecological risk analysis for the introduction of blue shrimp, Litopenaeus stylirostris, from Brunei Darussalam to Fiji. A consultancy report prepared for the Secretariat of the Pacific Community, Noumea Cedex, and New Caledonia. 82 pp.

Burford, M.A., William, K.C., 2001. The fate of nitrogenous waste from shrimp feeding. Aquaculture 198, 79-93.

Chen, J-C., Liu, P-C., Lei, S-C., 1990. Toxicities of ammonia and nitrite to penaeus monodon adolescents. Aquaculture 89, 127-137.

Cruz, P.S., Andalecio, M.N., Bolivar, R.B., Fitzsimmons, K., 2008. Tilapia-shrimp polyculture in Negros Island, Philippines: A Review. Journal of the World Aquaculture Society 39(6), 713-725.

Cruz-Suárez, L.E., León, A., Pena-Rodríguez, A., Rodríguez-Pena, G., Moll, B., RicqueMarie D., 2010. Shrimp/Ulva co-culture: A sustainable alternative to diminish the need for artificial feed and improve shrimp quality. Aquaculture 301, 64-68.

Díaz, F., Re-Araujo, A., Sierra, E., Díaz Iglesias, E., 2004. Effects of temperature and salinity fluctuation on the oxygen consumption, ammonium excretion and osmoregulation of the blue shrimp Litopenaeus stylirostris (Stimpson). Journal of Shellfish Resources 23, 903 910.

Eldani, A., Primavera, J.H., 1981. Effect of different stocking combinations on growth production and survival of milkfish (Chanos chanos Forskal) and prawn (Penaeus monodon Fabricus) in polyculture in brackishwater ponds. Aquaculture 23, 59-72.

Ellis, M.S., 1992. Oxygen, carbon and sulfur cycling in the sediments of hypereutrophic mesocosms (shrimp mariculture ponds). MSc thesis, Texas A\&M University, Texas. 152 pp.

FAO, 2010. Fishery and Aquaculture Statistics 2010. Rome/Roma, FAO. 78 pp.

García-Pérez, A., Alston, D.E., Cortés-Maldonado, R., 2000. Growth, survival, yield, and size distributions of freshwater prawn Macrobrachium rosenbergii and tilapia 
Oreochromis niloticus in polyculture and monoculture system in Puerto Rico. Journal of the World Aquaculture Society 31(3), 446-451.

Goarant, C., Ansquer, D., Herlin, J., Domalain, D., Imbert, F., Decker, S.D., 2006. "Summer syndrome" in Litopenaeus stylirostris in New Caledonia: Pathology and epidemiology of the etiological agent, Vibrio nigripulchritudo. Aquaculture 253, 105-113.

Holm-Hansen, O., Lorenzen, C.J., Holms, P.E., Strickland, J.D.H., 1965. Fluorometric determination of chlorophyll. Journal du conseil International pour l'exploitation de la mer 30, 3-15.

Hussenot, J., Martin, J.L.M., 1995. Assessment of the quality of pond sediment in aquaculture using simple rapid techniques. Aquaculture International 3, 123-133.

Joyni, M.J., Kurup, B.M., Avnimelech, Y., 2011. Bioturbation as a possible means for increasing production and improving pond soil characteristics in shrimp-fish brackish water ponds. Aquaculture 318, 464-470.

Kumaraguru Vasagam, K.P., Suresh, A.V., Chamberlain, G.W., 2009. Growth performance of blue shrimp, Litopenaeus stylirostris in self-cleaning microcosm tanks. Aquaculture 290, 236-242.

Koroleff, F., 1976. Determination of ammonia. In: Methods in Seawater Analysis (ed. by K. Grasshof). Verlag Chemie Weineim, RFA. pp. 126-133

Lam, T.J., 1974. Siganids: their biology and mariculture potential. Aquaculture 3, 325-354.

Lazur, A., 2007. Growout pond and water quality management. Joint Institute of Food Safety and Applied Nutrition, University of Maryland, $17 \mathrm{pp}$.

Lemonnier, H., Bernard, E., Boglio, E., Goarant, C., Cochard, J.-C., 2004. Influence of sediment characteristics on shrimp physiology: $\mathrm{pH}$ as principal effect. Aquaculture 240, 297-312.

Lemonnier, H., Faninoz, S., 2006. Effect of water exchange on effluent and sediment characteristics and on partial nitrogen budget in semi-intensive shrimp ponds in New Caledonia. Aquaculture Research 37, 938-948.

Lemonnier, H., Herbland, A., Salery, L., Soulard, B., 2006. "Summer syndrome" in Litopenaeus stylirostris in grow-out ponds in New Caledonia: Zootechnical and environmental factors. Aquaculture 261, 1039-1047. 
Lombardi, J.V., de Marques, H.L.A., Pereira, R.T.L., Barreto, O.J.S., de Paula, E.J., 2006. Cage polyculture of the Pacific whiter shrimp Litopenaeus vannamei and the Philippines seaweed Kappaphycus alvarezii. Aquaculture 258, 412-415.

MacIntyre, H.L., Geider, R.J., Miller, D.C., 1996. Microphytobenthos: the ecological role of the "secret garden" of unvegetated, shallow-water marine habitats. 1. Distribution, abundance and primary production. Estuaries 19(2A): 186-201.

Martínez-Córdova, L.R., Pena-Messina E., 2005. Biotic communities and feeding habits of Litopenaeus vannamei (Boone 1931) and Litopenaeus stylirostris (Stimpson 1974) in monoculture and polyculture semi-intensive ponds. Aquaculture research 36, 1075-1084.

Martínez-Córdova, L.R., Martínez-Porchas, M., 2006. Polyculture of Pacific white shrimp, Litopenaeus vannamei, giant oyster, crassostrea gigas and black clam, Chione fluctifraga in ponds in Sonora, Mexico. Aquaculture 258, 321-326.

Martínez-Porchas, M., Martínez-Córdova, L.R., Porchas-Cornejo, M.A. and López-Elías, J.A., 2010. Shrimp polyculture: a potentially profitable, sustainable, but uncommon aquacultural practice. Reviews in Aquaculture 2, 73-85.

Mermoud, I., Costa, R., Ferré, O., Goarant, C., Haffner, P., 1998. 'Syndrome 93' in New Caledonia outdoor rearing ponds of Penaeus stylirostris: history and description of three major outbreaks. Aquaculture 164, 323-335.

Mugnier, C., Lemonnier, H., Legrand, A., 2006. Physiological response of the blue shrimp Litopenaeus stylirostris to short-term confinement on a pond bottom. Aquaculture 253, 703-711.

Murphy, J., Riley, J.P., 1962. A single solution method for the determination of soluble phosphate in sea water. Journal of the Marine Biology Association of the United Kingdom, 37: 9-14.

Nelson, D.W., Sommers, L.E., 1996. Total carbon, organic carbon, and organic matter. In: Methods of Soil Analysis. Part 2, $2^{\text {nd }}$ ed., Page A.L., et al., Ed. Agronomy 9: 961-1010. America Society of Agronomy, Inc., Madison, Wisconsin, USA.

Raimbault, P., Pouvesle, W., Diaz, F., Garcia, N., Sempéré, R., 1999. Wet-oxidation and automated colorimetry for simultaneous determination of organic carbon, nitrogen and phosphorus dissolved in sea water. Marine Chemistry 66, 161-169.

Salame, M., 1993. Feeding trays in penaeid shrimp ponds. Aquaculture Magazine 19(4), 5963. 
Saoud, I.P., Ghanawi, J., Lebbos, N., 2008a. Effects of stocking density on the survival, growth, size variation and condition index of juvenile rabbitfish Siganus rivulatus. Aquaculture International. 16: 109-116.

Spanopoulos-Hernández, M., Martinez-Palacios, C.A., Vanegas-Pérez, R.C., Rosas, C., Ross, L.G., 2005. The combined effect of salinity and temperature on the oxygen consumption of juvenile shrimp Litopenaeus stylirostris (Stimpson 1874). Aquaculture 244, 341-348.

Strickland, J. D. H., Parsons, T. R., 1972. A practical handbook of seawater analysis. Bulletin 167, Fisheries Research Board of Canada, Ottawa. 310pp.

Suplee, M.W., Cotner, J.B., 1996. Temporal changes in oxygen demand and bacterial sulfate reduction in inland shrimp ponds. Aquaculture 145, 141-158.

Tendencia, E. A., dela Pena, M.R., Choresca Jr, C.H., 2006a. Presence of snapper, seabass, and siganid inhibits growth of luminous bacteria in a simulated shrimp culture system. Aquaculture 260, 54-60.

Tendencia, E.A., Fermin, A.C., dela Pena, M.R., Choresca Jr, C.H., 2006b. Effect of Epinephelus coioides, Chanos chanos, and GIFT tilapia in polyculture with Penaeus monodon on the growth of the luminous bacteria Vibrio harveyi. Aquaculture 253, 48-56.

Tendencia, E. A., dela Pena, M.R., Choresca Jr, C.H., 2006c. Effect of shrimp biomass and feeding on the anti-Vibrio harveyi activity of Tilapia sp. in a simulated shrimp-tilapia polyculture system. Aquaculture, 154-162.

Thomas, Y., Courties, C., Helwe E, Y., Herbland, A., Lemonnier, H., 2010. Spatial and temporal extension of eutrophication associated with shrimp farm wastewater discharges in the New Caledonia lagoon. Marine Pollution Bulletin 61, 387-398.

Tian, X., Li, D., Dong, S., Yan, X., Qi, Z., Liu, G., Lu, J., 2001. An experimental study on closed-polyculture of penaeid shrimp with tilapia and constricted tagelus. Aquaculture 202, 57-71.

Uddin, M.S., Milsten, A., Azim, M.E., Wahab, M.A., Verdegem, M., Verreth, J., 2008. Effects of stocking density, periphyton substrate and supplemental feed on biological processes affecting water quality in earthen tilapia-prawn polyculture ponds. Aquaculture Research 39, 1243-1257.

Wabete, N., Chim, L., Lemaire P., Massabuau J.-C., 2008. Life on the edge: physiological problems in penaeid prawns Litopenaeus stylirostris, living on the low side of their thermopreferendum. Marine Biology 154, 404-412. 
Wang, J-Q., Li, D., Dong, S., Wang, K., Tian, X, 1998, Experimental studies on polyculture in closed shrimp ponds: I. Intensive polyculture of Chinese shrimp (Penaeus chinesis) with tilapia hybrids, Aquaculture 163, 11-27.

Wood, E.D., Armstrong, F.A.J., Richards F.A., 1967. Determination of nitrate in sea water by cadmium copper reduction to nitrite. Journal of the Marine Biological Association of the United Kingdom, 47, 23-31.

Wyban, J., Wash, W.A., Godin, D.M., 1995. Temperature effect on growth, feeding rate and feed conversion of the pacific white shrimp Panaeus vannamei. Aquaculture 138, 267279.

Yuan, D., Yi, Y., Yakupitiyage, A., Firzimmons, K., Diana, J.S., 2010. Effects of addition of red tilapia (Oreochromis spp.) at different densities and sizes on production, water quality and nutrient recovery of intensive culture of white shrimp (Litopenaeus vannamei) in cement tanks. Aquaculture 298, 226-238. 

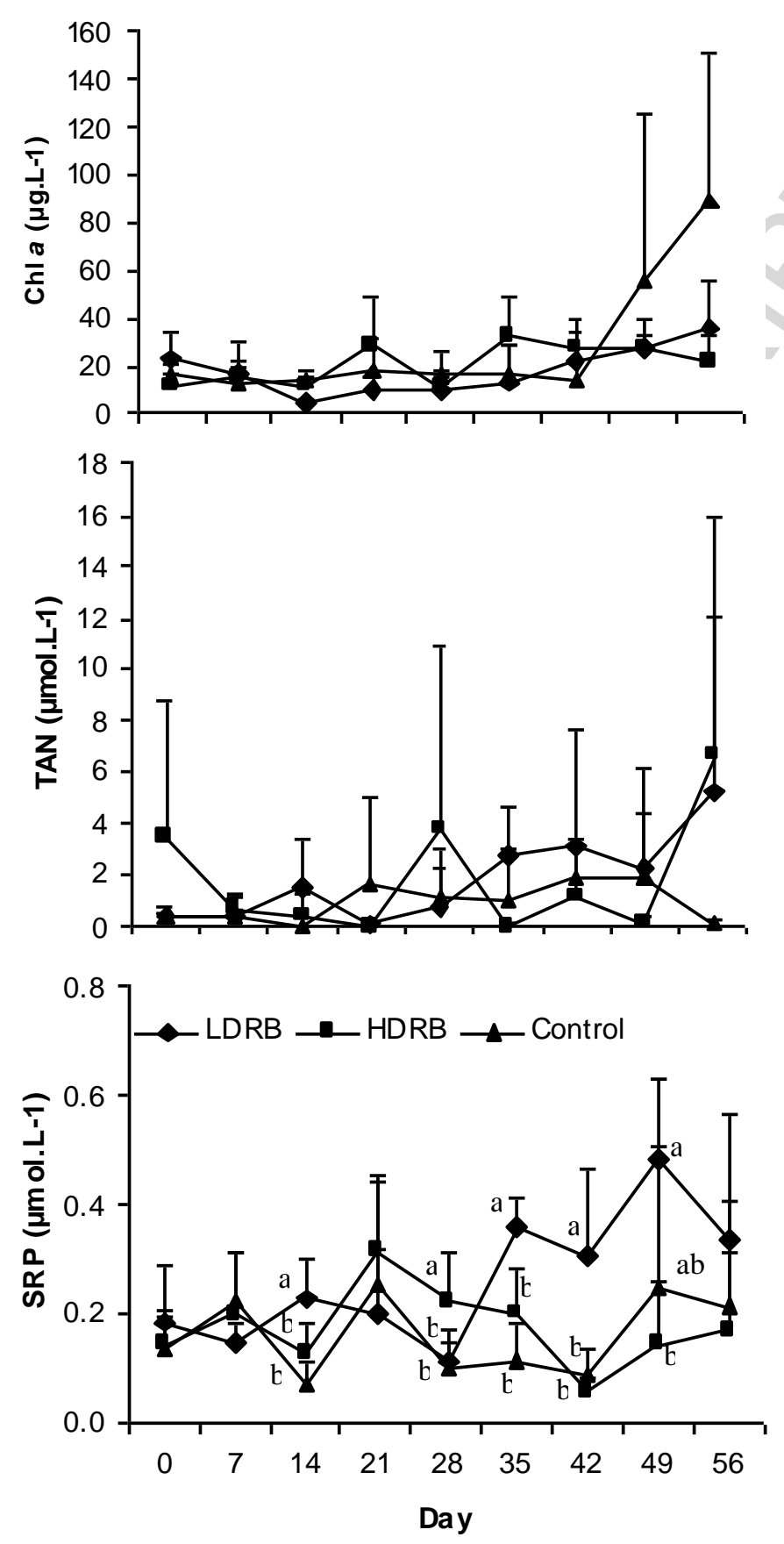

Figure 1: Temporal variation of water Chl $a$, TAN, and SRP in the LDRB and the HDRB polyculture and the control throughout the experimental period. Bars presented standard deviations. Values in the same day with different letters are significantly different $(\mathrm{P}<0.05)$ 


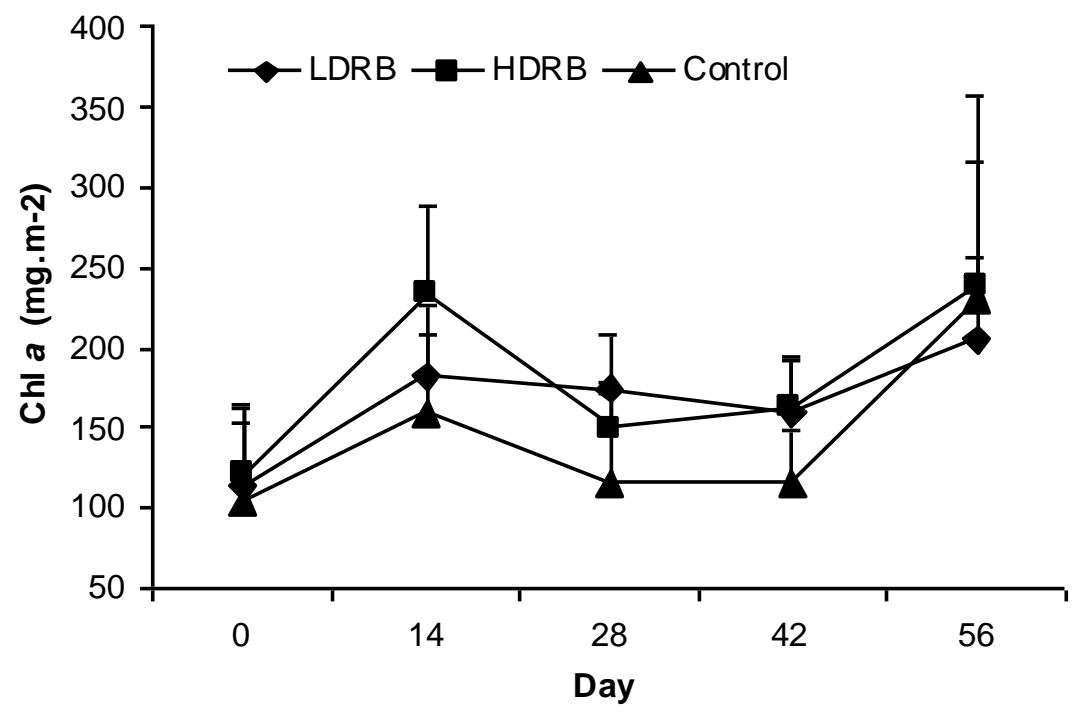

Figure 2: Temporal variations of sediment Chl $a$ in the LDRB and the HDRB polyculture and the control throughout the experimental period. Bars presented standard deviations. 

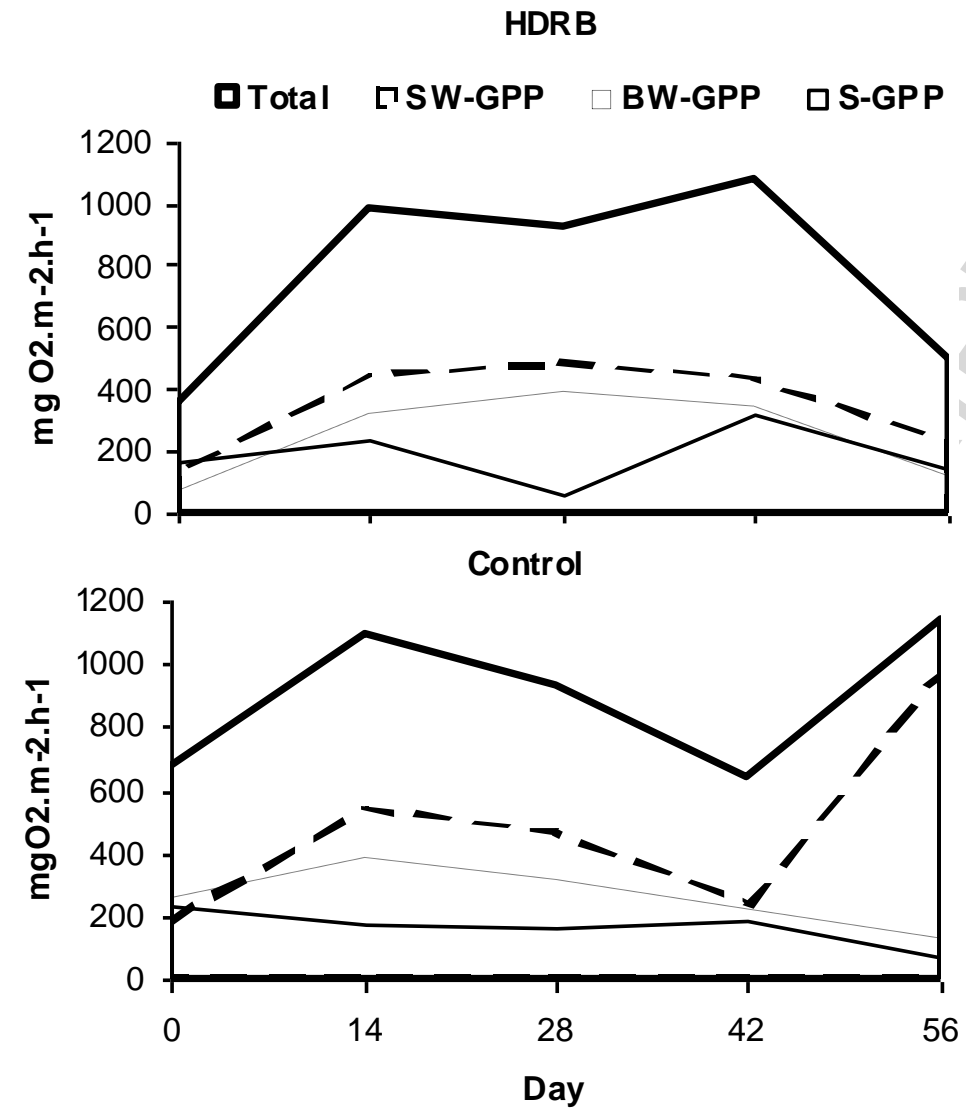

Figure 3: Temporal variations of GPP in the HDRB polyculture and the control; total: gross primary productivity in whole tank, SW-GPP: surface water gross primary productivity, BWGPP: bottom water gross primary productivity, and S-GPP: sediment gross primary productivity, 

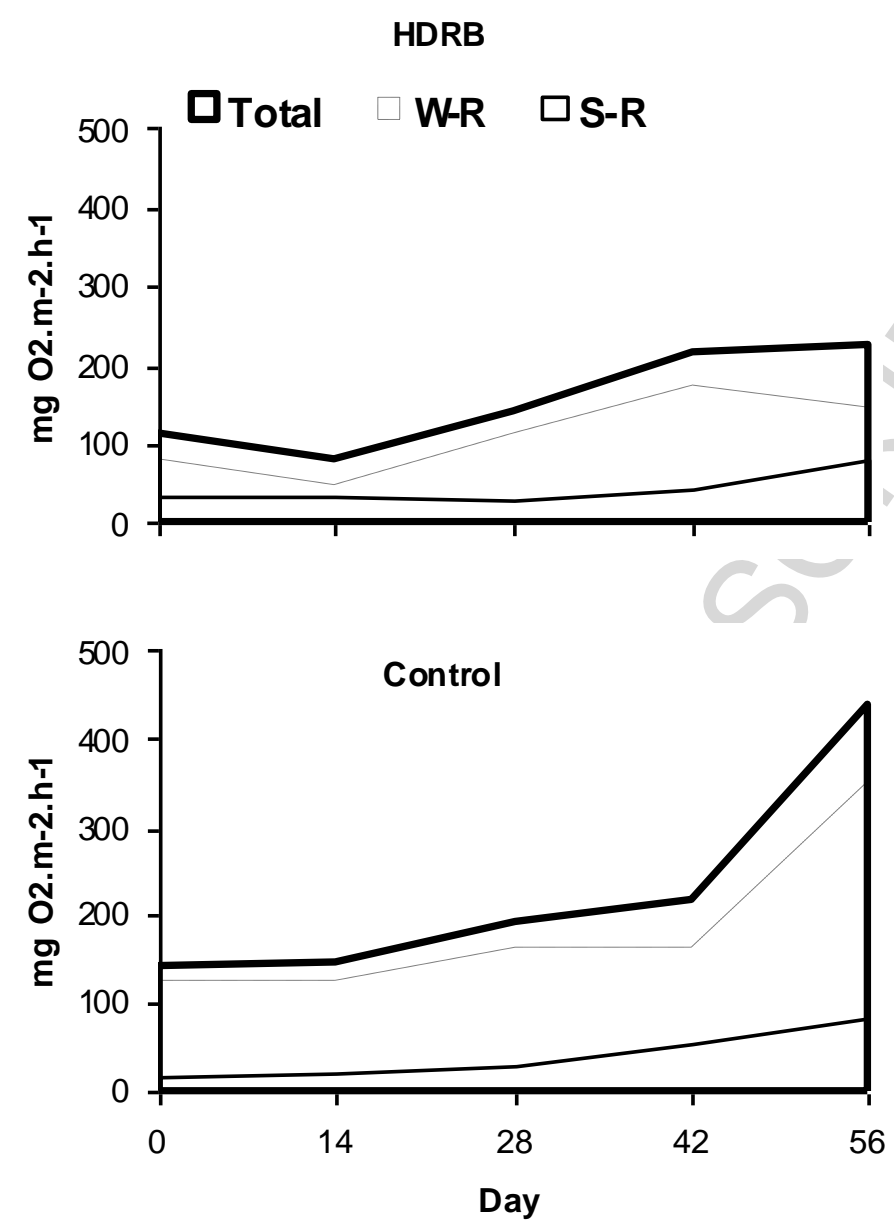

Figure 4: Temporal variations of respiration in the HDRB polyculture and the control; total: respiration in whole tank, W-R: water respiration, S-R: sediment respiration 


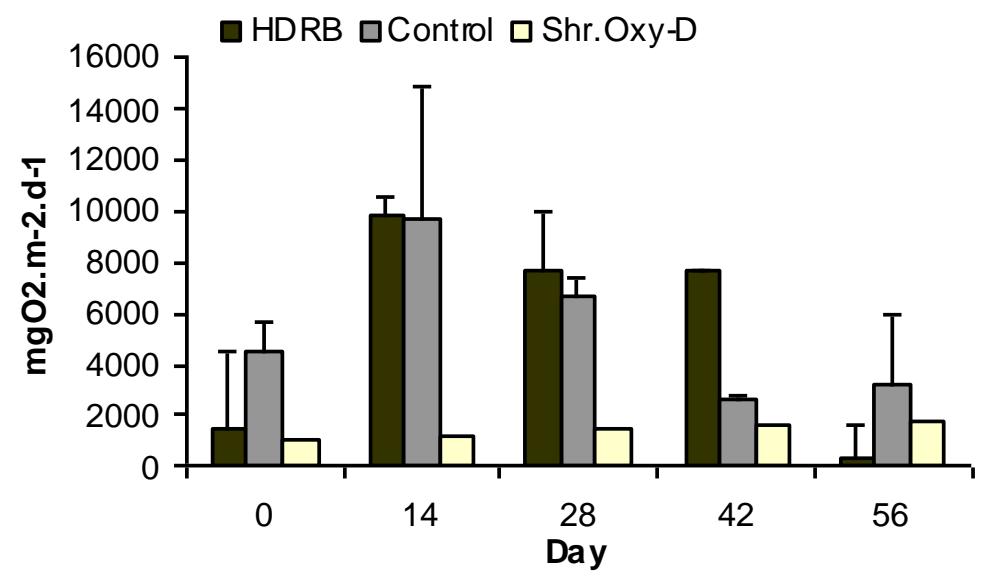

Figure 5: Oxygen budget produced by oxygen metabolism in the HDRB polyculture and the control in comparison with shrimp oxygen demand (Shr.Oxy-D) throughout the experiment. Blue shrimp, L. stylirostris, consume an average amount of $11.3 \mathrm{mgO}_{2} \cdot \mathrm{g}^{-1} \cdot \mathrm{d}^{-1}$ at stage used for the experiment (Wabete et al., 2008) 


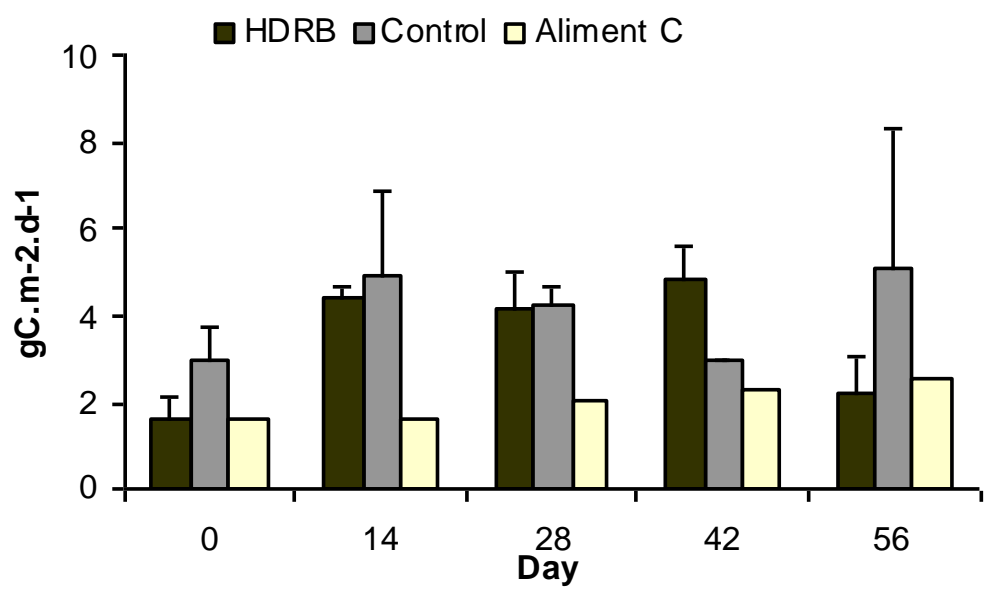

Figure 6: Gross natural production produced by algae photosynthesis in the HDRB polyculture and the control in comparison with organic carbon daily supplied from pellet feed (Aliment C). 
Table 1: Blue shrimp and goldlined rabbitfish growth parameters for polyculture of blue shrimp with goldlined rabbitfish at different stocking densities and shrimp monoculture. Values are mean $\pm \mathrm{SD}$

\begin{tabular}{|c|c|c|c|}
\hline & \multicolumn{3}{|c|}{ Treatment } \\
\hline & Control & $\begin{array}{l}\text { Low density } \\
\text { rabbitfish }\end{array}$ & $\begin{array}{l}\text { High density } \\
\text { rabbitfish }\end{array}$ \\
\hline \multicolumn{4}{|l|}{ Shrimp } \\
\hline Final mean weight (g.shrimp ${ }^{-1}$ ) & $14.0 \pm 0.7^{\mathrm{a}}$ & $13.4 \pm 0.9^{\mathrm{a}}$ & $13.9 \pm 0.2^{\mathrm{a}}$ \\
\hline DWG $\left(g . d^{-1}\right)$ & $0.13 \pm 0.01^{\mathrm{a}}$ & $0.13 \pm 0.01^{\mathrm{a}}$ & $0.13 \pm 0.02^{\mathrm{a}}$ \\
\hline $\operatorname{SGR}\left(\% . \mathrm{d}^{-1}\right)$ & $1.89 \pm 0.06^{\mathrm{a}}$ & $1.83 \pm 0.08^{\mathrm{a}}$ & $1.88 \pm 0.12^{\mathrm{a}}$ \\
\hline Survival (\%) & $66.3 \pm 20.7^{\mathrm{a}}$ & $71.2 \pm 13.1^{\mathrm{a}}$ & $80.8 \pm 7.0^{\mathrm{a}}$ \\
\hline $\mathrm{CV}$ in survival (\%) & 31.2 & 18.5 & 8.7 \\
\hline Yield $\left(\mathrm{g} \cdot \mathrm{m}^{-2} \cdot 84 \mathrm{~d}^{-1}\right)$ & $143.2 \pm 48.6^{\mathrm{a}}$ & $145.4 \pm 24.7^{\mathrm{a}}$ & $170.3 \pm 27.0^{\mathrm{a}}$ \\
\hline CV in yield (\%) & 33.9 & 17.0 & 15.9 \\
\hline FCR & $3.8 \pm 1.6^{\mathrm{a}}$ & $3.7 \pm 0.7^{\mathrm{a}}$ & $2.9 \pm 0.5^{\mathrm{a}}$ \\
\hline \multicolumn{4}{|l|}{ Fish } \\
\hline Final mean weight (g.fish ${ }^{-1}$ ) & & $57.5 \pm 11.4^{\mathrm{a}}$ & $53.1^{\mathrm{a}} \pm 6.5$ \\
\hline DWG $\left(\right.$ g.fish $\left.{ }^{-1} \cdot d^{-1}\right)$ & & $0.58 \pm 0.22^{\mathrm{a}}$ & $0.50 \pm 0.09^{\mathrm{a}}$ \\
\hline $\operatorname{SGR}\left(\% \cdot \mathrm{d}^{-1}\right)$ & & $1.44 \pm 0.41^{\mathrm{a}}$ & $1.33 \pm 0.15^{\mathrm{a}}$ \\
\hline Fish yield $\left(\mathrm{g} \cdot \mathrm{m}^{-2} \cdot 56 \mathrm{~d}^{-1}\right)$ & & $67.7 \pm 13.5^{\mathrm{a}}$ & $125.0 \pm 15.4^{\mathrm{a}}$ \\
\hline \multicolumn{4}{|l|}{ Combined } \\
\hline Total yield (g.m ${ }^{-2}$ ) & $8.6^{\mathrm{a}}$ & $213.1 \pm 34.3^{b}$ & $295.3 \pm 24.4^{\mathrm{c}}$ \\
\hline FCRsf & $3.8 \pm 1.6^{\mathrm{a}}$ & $2.6 \pm 0.5^{\mathrm{ab}}$ & $2.0 \pm 0.3^{\mathrm{b}}$ \\
\hline
\end{tabular}

Mean values in a same row with different superscript letters were significantly different $(\mathrm{P}<0.05)$ 
Table 2: Water parameters in polyculture treatments and in the control throughout the experimental period. Values in parentheses are min - max. Values are means \pm SD

\begin{tabular}{|c|c|c|c|}
\hline & \multicolumn{3}{|c|}{ Treatment } \\
\hline & Control & $\begin{array}{l}\text { Low density } \\
\text { rabbitfish }\end{array}$ & $\begin{array}{l}\text { High density } \\
\text { rabbitfish }\end{array}$ \\
\hline \multirow[t]{2}{*}{$\mathrm{T}(07: 30)\left({ }^{0} \mathrm{C}\right)$} & $22.4 \pm 0.3$ & $22.5 \pm 0.1$ & $22.4 \pm 0.2$ \\
\hline & $(17.5-28.2)$ & $(17.6-28.0)$ & $(17.7-28.1)$ \\
\hline \multirow[t]{2}{*}{$\mathrm{T}(15: 00)\left({ }^{0} \mathrm{C}\right)$} & $26.5 \pm 0.3$ & $26.4 \pm 0.1$ & $26.4 \pm 0.5$ \\
\hline & $(22.3-31.7)$ & $(22.4-31.4)$ & $(21.7-32.8)$ \\
\hline \multirow[t]{2}{*}{ DO $(07: 30)\left(\mathrm{mg} . \mathrm{L}^{-1}\right)$} & $5.7 \pm 0.2$ & $5.5 \pm 0.2$ & $5.5 \pm 0.1$ \\
\hline & $(1.6-7.6)$ & $.6)$ & $(2.1-7.4)$ \\
\hline \multirow[t]{2}{*}{ DO $(15: 00)\left(\mathrm{mg} \cdot \mathrm{L}^{-1}\right)$} & $9.3 \pm 0.5$ & $9.2 \pm 0.1$ & $9.4 \pm 0.1$ \\
\hline & $(4.0-15.3)$ & $(5.0-15.0)$ & $(4.3-16.1)$ \\
\hline Turbidity (NTU) & $8.3 \pm 2.0^{\mathrm{a}}$ & $9.8 \pm 1.8^{\mathrm{a}}$ & $9.9 \pm 1.6^{\mathrm{a}}$ \\
\hline Chlorophyll $a\left(\mu \mathrm{g} . \mathrm{L}^{-1}\right)$ & $28.5 \pm 15.3^{\mathrm{a}}$ & $18.3 \pm 4.3^{\mathrm{a}}$ & $20.7 \pm 4.5^{\mathrm{a}}$ \\
\hline Phaeopigment (\%) & $30.2 \pm 2.6^{\mathrm{a}}$ & $35.0 \pm 2.8^{\mathrm{a}}$ & $32.8 \pm 5.0^{\mathrm{a}}$ \\
\hline $\operatorname{TDN}(\mu \mathrm{M})(\mathrm{n}=5)$ & $21.5 \pm 2.1^{\mathrm{a}}$ & $26.1 \pm 4.3^{\mathrm{a}}$ & $26.4 \pm 5.1^{\mathrm{a}}$ \\
\hline TAN $(\mu \mathrm{M})(\mathrm{n}=9)$ & $0.96 \pm 0.70^{\mathrm{a}}$ & $1.84 \pm 1.35^{\mathrm{a}}$ & $1.83 \pm 1.05^{\mathrm{a}}$ \\
\hline$\left(\mathrm{NO}_{2}+\mathrm{NO}_{3}\right)-\mathrm{N}(\mu \mathrm{M})(\mathrm{n}=5)$ & $0.20 \pm 0.04^{\mathrm{a}}$ & $0.19 \pm 0.06^{\mathrm{a}}$ & $0.25 \pm 0.08^{\mathrm{a}}$ \\
\hline $\operatorname{DON}(\mu \mathrm{M})(\mathrm{n}=5)$ & $20.6 \pm 2.2^{\mathrm{a}}$ & $23.7 \pm 1.9^{\mathrm{a}}$ & $23.1 \pm 3.4^{\mathrm{a}}$ \\
\hline $\operatorname{SRP}(\mu M)(n=9)$ & $0.16 \pm 0.07^{\mathrm{a}}$ & $0.26 \pm 0.04^{\mathrm{b}}$ & $0.17 \pm 0.03^{\mathrm{a}}$ \\
\hline
\end{tabular}


Table 3: Sediment parameters in polyculture treatments and in the control throughout the experimental period. Values are means \pm SD.

\begin{tabular}{lrrr}
\hline & \multicolumn{3}{c}{ Treatment } \\
\cline { 2 - 4 } & \multicolumn{1}{c}{ Control } & $\begin{array}{c}\text { Low density } \\
\text { rabbitfish }\end{array}$ & $\begin{array}{c}\text { High density } \\
\text { rabbitfish }\end{array}$ \\
\hline $\mathrm{pH}$ & $6.9 \pm 0.1$ & $6.9 \pm 0.0$ & $6.8 \pm 0.1$ \\
Redox potential $(\mathrm{mV})$ & $-34.0 \pm 11.9^{\mathrm{a}}$ & $-37.6 \pm 11.4^{\mathrm{a}}$ & $-27.1 \pm 23.8^{\mathrm{a}}$ \\
Loss on ignition $(\%)$ & $1.6 \pm 0.2$ & $1.6 \pm 0.2$ & $1.6 \pm 0.2$ \\
Chlorophyll $a\left(\mathrm{mg} . \mathrm{m}^{-2}\right)$ & $144.7 \pm 15.8^{\mathrm{a}}$ & $166.3 \pm 20.7^{\mathrm{a}}$ & $180.0 \pm 41.8^{\mathrm{a}}$ \\
Phaeopigment $(\%)$ & $25.6 \pm 3.7^{\mathrm{a}}$ & $26.6 \pm 1.9^{\mathrm{a}}$ & $25.8 \pm 3.6^{\mathrm{a}}$ \\
TAN $(\mu \mathrm{M})$ in pore water & $261.3 \pm 40.6^{\mathrm{a}}$ & $277.6 \pm 96.5^{\mathrm{a}}$ & $283.3 \pm 206.0^{\mathrm{a}}$ \\
SRP $(\mu \mathrm{M})$ in pore water & $2.3 \pm 1.1^{\mathrm{a}}$ & $2.4 \pm 0.8^{\mathrm{a}}$ & $1.4 \pm 0.4^{\mathrm{a}}$ \\
\hline
\end{tabular}

Mean values in a same row with same superscript letters were not significantly different $(\mathrm{P}>0.05)$ 


\section{Research highlights}

- Siganus lineatus does not affect Litopenaeus stylirostris growth in a polyculture system.

- Polyculture L. stylirostris and S. lineatus significantly increases pond production.

- Adding S. lineatus to L. stylirostris culture does not impact environmental quality.

- Adding S. lineatus to L. stylirostris culture does not affect pond metabolism. 